\title{
B. F. SKINNER-THE LAST FEW DAYS
}

My father always spoke admiringly of his grandfather's death. "He died with his boots on," he'd say, approvingly. Sometimes he would add, "That's the way I want to go." Well, he came close.

The last few months my father continued the pattern of his "retirement"; up early to write, breakfast, a walk, appointments with visitors and mail until lunch. Afternoons he usually spent relaxing with music and light reading, getting in shape for the next morning's work. To his death, the mail never let up. Inevitably among the letters from professional colleagues he would get a few letters from high school students asking him to explain his work. Letters to famous people are not always well informed. Senator Kennedy is said to have received a letter that said, "I have picked you as my favorite Senator. Can you tell me why?" The letters to my father were hardly better. Nevertheless, he answered them all, politely suggesting that if they checked their libraries they could probably find a book called Walden Two or Science and Human Bebavior that would answer their questions.

Eight days before his death, as readers of this journal probably know, my father received, from the American Psychological Association, the first APA Citation for Outstanding Lifetime Contribution to Psychology. The association officials had assured the family that they would keep my father from crowds-important because of his heightened susceptibility to infection from leukemia - and they kept their word. At 1:00 o'clock on August 10th, a limousine appeared at the Skinner home to drive our party to the convention hotel. There we were met and ushered upstairs in our own elevator to a hotel room, "like movie stars," my father remarked. A few minutes before the opening session was to begin, we were ushered back downstairs and taken by a back way to the side door of the auditorium. I was holding my father's arm as we entered. The room was packed. A second room to the side had been opened and it, too, was overflowing. When we had taken two steps into the room everyone stood up and began to applaud. My father made an awkward nod of his head in acknowledgment as he continued walking - I could tell he hadn't expected such a reception. The applause was thunderous. It continued as we made our way to the bottom of the steps at the middle of the stage. It continued as my father made his way up the steps. It continued, undiminished, as my father was escorted across the stage to his chair. He turned around and made a gracious bow of his head, but there was no sign of the applause letting up. Finally, APA officials interrupted the applause and started the program. After 50 minutes of preliminaries, it was time for my father to accept the award.

I was glad that he had decided not to use a text or even notes, for the glaring light from the TV camera crews would have made it impossible for him to have seen anything. He began. "President Graham, past-President Matarazzo, distinguished guests, ladies and gentlemen..."1 $\mathrm{He}$ talked smoothly, the way I had heard him talk at dozens of conventions, complete with names and dates I would have had trouble remembering. The talk turned to the split in psychology, "one part going in the direction of finding out the essence of the feeling, the essence of the cognitive process, and the other going in the direction of references to contingencies of reinforcement." He drew an analogy between the difficulty of acceptance of Darwin's natural selection and the difficulty of acceptance of Skinner's own selection by consequences, culminating in the statement, "So far as I'm concerned, cognitive science is the creationism of psychology." The whole audience gasped audibly. A sprinkling of clapping could be heard here and there. (Clearly the split was not 50-50.) Skinner continued, ending in just over 15 minutes - as he had planned. After being escorted down the stairs (again to ap-

'All quotes are from extemporaneous comments made by B. F. Skinner upon receiving APA's lifetime award at the opening session of the American Psychological Association's 98th Annual Convention on August 10, 1990, in Boston. 
plause), he left. So, I am afraid, did almost all of the rest of the audience.

Over the weekend, my father worked on the paper from which his remarks were taken. It was to go in The American Psychologist and he was anxious to finish it. We talked about the futurewhat he would work on next. He didn't feel he would have time to complete the work he had done on the derivations of words, or to put into article form material from a book on ethics he had begun but given up. As it turned out, he was right about time.

Monday morning my father had an hour interview with Dan Bjork, a historian who had been working on a biography of him. In the afternoon, I took him for his usual platelet transfusion. That evening I was working in the den I had created out of a store room in the basement when I got a call. It was my father. "Julie, could you come here?" I rushed to his study to find him shivering under several blankets in his reclining chair. I panicked. The symptoms were the same as those that had put him into a coma one time before. Unable to reach a doctor, I called 911 . By the time the ambulance arrived he was feeling better, although his heart was still racing. The ambulance team gave him oxygen and took all sorts of measures, conferring by phone with medical personnel from his infirmary. My father didn't want to go back to the hospital, so, because he appeared stable, the team left. The oxygen had made him feel better, so I hooked up an old tank he had saved from years ago. I encouraged him to stay sitting up because his heart was still racing, and a sitting position is less strain on the heart. He agreed, and took out a book to read. I set up a cot in his study and brought in my guitar. For an hour I played for him -all of the classical pieces I could play reasonably well. It pleased him. He hadn't heard me play in some time and commented on the "richness" of the sound. The oxygen and I both ran out about the same time. Later, in his bed, a Japanesedesigned sleeping cubicle in the far corner of his study, we talked. I sat on the edge, holding his hand, as so many times, dewy-eyed, he had held mine when putting me to bed as a child. Only this time there were tears in both of our eyes.

I awoke the next morning to find him awake, but weak. In spite of my urging, he refused to cancel a TV crew scheduled to take footage for that night's newscast. Wednesday morning, another interview. That afternoon he went into the hospital for the last time. But the day before he died, in the hospital, he worked on the last changes in his paper for The American Psychologist.

B. F. Skinner was a member of the Hemlock Society and believed in the right to take one's own life. He had made a living will and, in the hospital, again refused "heroic" lifesaving efforts that could have prolonged the functioning of his organs. Near the end, his mouth was dry. Upon receiving a bit of water he said his last word, "Marvelous."

$$
\begin{aligned}
& \text { JuLie S. VARGAS } \\
& \text { Morgantown, West Virginia } \\
& \text { October, } 1990
\end{aligned}
$$

